\title{
Peran Guru Dalam Mengajarkan Nilai Penjas Kepada Siswa
}

\author{
Moch Fath Khurrohman \\ Universitas Negeri Yogyakarta
}

\begin{abstract}
Abstrak
Pendidikan Jasmani merupakan salah satu mata pelajaran yang terstruktur dan sistematik untuk memperoleh pengetahuan, kepribadian, keterampilan melalui aktivitas fisik. Pendidikan jasmani juga berperan dalam upaya meningkatkan performa individu untuk mengarahkan ke peningkatan kualitas tubuh, watak atau sikap dan kepribadian menjadi lebih baik. Nilai-nilai penting terkandung dalam pendidikan jasmani yang berguna untuk kehidupan peserta didik nantinya di kehidupan masyarakat.

Selanjutnya, diuraikan mengenai penjelasan dari olahraga dan pendidikan jasmani, tujuan pembelajaran pendidikan jasmani, nilai-nilai yang terkandung dalam pendidikan jasmani, dan peran guru untuk menerapkan nilai-nilai tersebut kepada peserta diidk. Keterlibatan masyarakat masih tergolong minimal dalam penerapan nilai-nilai pendidikan jasmani, maka dari itu guru memiliki peranan penting untuk semaksimal mungkin menerapkan nilai-nilai pendidikan jasmani melalui proses pembelajaran di sekolah.

Kukuhnya landasan ilmiah dalam upaya kependidikan pada pendidikan jasmani menuntun kearah proses pembelajaran yang efektif demi pencapaian tujuan yang diharapkan. Hanya dengan landasan ilmiah yang kukuh baru akan terjamin prinsip akuntabilitas dalam pendidikan jasmani, dan atas dasar itu pula guru di bidang olahraga dapat mempertanggungjawabkan demi upaya penerapan nilai-nilai pendidikan jasmani kepada peserta didik untuk diterapkan dalam kehidupan bermasyarakat.
\end{abstract}




\section{KATA PENGANTAR}

Puji syukur atas karunia yang Allah SWT berikan, atas limpahan rahmat, dan kasih sayang-Nya, atas petunjuk dan bimbingan yang telah diberikan, sehingga penulis dapat menyelesaikan makalah yang berjudul "Peran Guru Dalam Mengajarkan Nilai Penjas Kepada Siswa”. Dalam kesempatan ini, penulis ingin menyampaikan ucapan terima kasih sedalamdalamnya kepada semua pihak, yang telah memberikan bantuan berupa bimbingan, arahan, motivasi, dan doa selama proses penulisan makalah ini.

Teriring harapan dan doa semoga Allah SWT. Membalas amal kebaikan dari berbagai pihak tersebut. Tentunya masih banyak kekurangan yang ada dalam penulisan makalah ini, untuk itu penulis sangat berharap masukan dari pembaca dan semoga karya ilmiah ini bisa bermanfaat bagi siapa saja yang membacanya.

Yogyakarta, Januari 2021

Penulis 


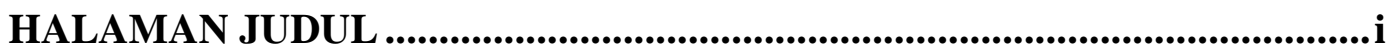

KATA PENGANTAR ........................................................................ ii

DAFTAR ISI ....................................................................................................iii

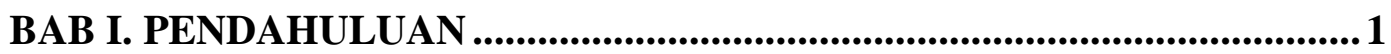

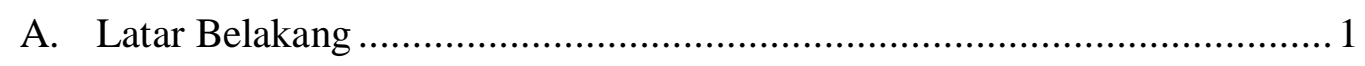

B. Rumusan Masalah ................................................................................... 2

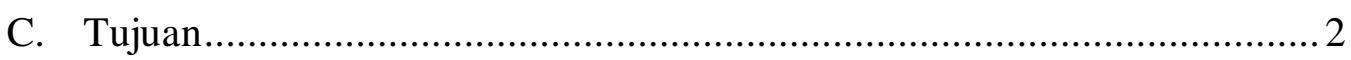

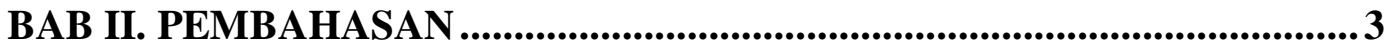

A. Olahraga dan Pendidikan Jasmani ................................................... 3

B. Tujuan Pendidikan Jasmani .......................................................... 3

C. Nilai-Nilai dalam Pendidikan Jasmani .................................................... 5

D. Peran Guru Untuk Menerapkan Nilai Pendidikan Jasmani ........................ 6

BAB III. KESIMPULAN DAN SARAN ....................................................9

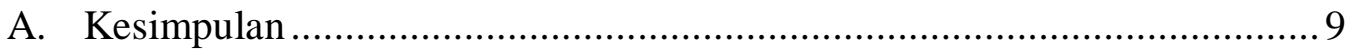

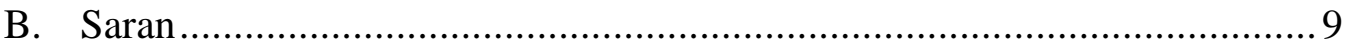

DAFTAR PUSTAKA ..................................................................................... 10 


\section{BAB I. PENDAHULUAN}

\section{A. Latar Belakang}

Olahraga merupakan salah satu upaya dalam meningkatkan performa individu untuk mengarahkan ke peningkatan kualitas tubuh, watak atau sikap dan kepribadian, serta peningkatan prestasi cabang olahraga (Dwyer \& Gabret, 2012:818). Kegiatan berolahraga telah mencakup beberapa macam, seperti olahraga prestasi, olahraga rekreasi, dan olahraga pendidikan. Olahraga prestasi dilakukan secara profesional dengan tujuan untuk mencapai prestasi. Selanjutnya, olahraga rekreasi dilakukan melalui kegiatan yang bersifat menyenangkan seperti pariwisata, permainan, dan sebagainya. Sedangkan olahraga pendidikan merupakan kegiatan yang dimasukkan ke dalam mata pelajaran yang terlibat untuk pencapaian tujuan pendidikan.

Pendidikan Jasmani merupakan salah satu mata pelajaran yang terstruktur dan sistematik untuk memperoleh pengetahuan, kepribadian, keterampilan melalui aktivitas fisik. Olahraga ataupun pendidikan jasmani di cap sebagai hal yang baik oleh masyarakat umum (Devine \& Tevler, Whitehead et al., 2014:15). Perlu diketahui, bahwa dalam pendidikan jasmani terdapat nilai-nilai penting yang terkandung, diantaranya motivasi untuk berperilaku secara sukarela, kegigihan, dan peningkatan yang terukur (Chen \& Liu, 2009). Lebih lanjut, pendidikan jasmani juga mengandung nilai-nilai karakter seperti sportivitas, kejujuran, keberanian, kerja keras, semangat tinggi, kerjasama, dan keadilan (Yuliawan, 2016:101). Maka dari itu, peran dari guru pendidikan jasmani sangat dibutuhkan dalam penerapan nilai-nilai tersebut. Lantas apakah semua nilai-nilai yang terkandung sudah tertanam ke masyarakat terutama peserta didik?

Ada satu permasalahan yang disebutkan oleh (Whitehead et al., 2014) bahwa keterlibatan masyarakat masih tergolong minimal dalam penerapan nilai-nilai pendidikan jasmani. Maka dari itu, dalam makalah ini penulis akan menjelaskan mengenai bagaimana cara mengajarkan nilai melalui pendidikan jasmani di masyarakat terutama kepada peserta didik. 


\section{B. Rumusan Masalah}

Adapun rumusan masalah dalam makalah ini yaitu bagaimana cara atau peran guru dalam mengajarkan nilai melalui pendidikan jasmani?

\section{Tujuan}

Tujuan yang ada pada makalah ini, yaitu untuk mengetahui cara atau peran guru dalam mengajarkan nilai melalui pendidikan jasmani. 


\section{BAB II. PEMBAHASAN}

\section{A. Olahraga dan Pendidikan Jasmani}

Olahraga dan pendidikan jasmani semakin mengalami peningkatan penting dalam kurikulum pendidikan. Pendidikan telah mengakui bahwa olahraga bukan sekedar aktivitas manusia yang tidak penting dalam masyarakat. Olahraga dan pendidikan jasmani merupakan sebuah aktivitas yang layak dipelajari dari berbagai pendekatan disiplin ilmu, sehingga dampak dan pentingnya olahraga dapat dinilai dan mengerti (Chandler et al., 2002:165).

Pendidikan jasmani merupakan cakupan dalam olahraga pendidikan yang digunakan sebagai alat untuk mencapai tujuan pendidikan. Pendidikan jasmani adalah salah studi bidang studi atau mata pelajaran yang dilaksanakan di sekolah (Festiawan, 2015). Sub disiplin ilmu pada pendidikan jasmani mengajarkan 3 ranah pembelajaran secara langsung, meliputi aspek kognitif, afektif, dan fundamental psikomotor untuk memenuhi kebutuhan unik peserta didik (Vickerman \& Maher, 2018:56).

Dari beberapa pendapat ahli di atas, olahraga dan pendidikan jasmani merupakan suatu hal penting yang memiliki nilai tersendiri untuk individu.

\section{B. Tujuan Pendidikan Jasmani}

Henry (1964) dikutip dari (Laker, 2003) menyatakan bahwa pendidikan jasmani memiliki bidang keilmiahan pengetahuan yang meliputi anatomi, fisika, fisiologi, antropologi budaya, sejarah, dan sosiologi. Tujuan penting dari pendidikan jasmani adalah mengembangkan kebiasaan perilaku untuk melakukan aktivitas jasmani dalam menjaga kesehatan. Dengan kata lain, individu diharapkan yang menerima pendidikan jasmani, akan dapat memotivasi diri sendiri untuk terlibat di dalamnya aktivitas fisik itusendiri. Adapun tujuan dari pendidikan jasmani berdasarkan Permendiknas Nomor 22 Tahun 2006, diantaranya: 
1. Mengembangkan keterampilan pengelolaan diri dalam upaya pengembangan dan pemeliharaan kebugaran jasmani serta pola hidup sehat melalui berbagai aktivitas jasmani dan olahraga yang terpilih.

2. Meningkatkan pertumbuhan fisik dan pengembangan psikis yang lebih baik.

3. Meningkatkan kemampuan dan keterampilan gerak dasar.

4. Meletakkan landasan karakter moral yang kuat melalui internalisasi nilainilai yang terkandung di dalam pendidikan jasmani, olahraga dan kesehatan.

5. Mengembangkan sikap sportif, jujur, disiplin, bertanggung jawab, kerja sama, percaya diri dan demokratis.

6. Mengembangkan keterampilan untuk menjaga keselamatan diri sendiri, orang lain dan lingkungan.

7. Memahami konsep aktivitas jasmani dan olahraga di lingkungan yang bersih sebagai informasi untuk mencapai pertumbuhan fisik yang sempurna, pola hidup sehat dan kebugaran, terampil serta memiliki sikap yang positif.

Sedangkan menurut (Suherman, 2009), ada empat tujuan umum dalam pendidikan jasmani, sebagai berikut:

1. Perkembangan fisik

Tujuan ini berhubungan dengan kemampuan dalam melakukan aktivitas yang melibatkan kekuatan fisik dari organ tubuh seseorang sehingga akan terjadi pembentukan/perkembangan dari bagian anggota tubuh.

2. Perkembangan gerak

Tujuan ini berhubungan dengan kemampuan untuk melakukan keluwesan gerak secara efektif dan efisien.

3. Perkembangan mental

Tujuan ini berhubungan dengan kemampuan berfikir dan menginterpretasikan keseluruhan pengetahuan tentang pendidikan jasmani ke dalam lingkungannya. Perkembangan mental didapatkan melalui peranan psikologi pendidikan jasmani yang didalamnya terdapat ilmu 
tentang melatih keterampilan mental seperti motivasi, kesadaran diri, dan kepercayaan diri (Komarudin, 2017:5).

4. Perkembangan sosial

Tujuan ini berhubungan dengan kemampuan siswa dalam menyesuaikan diri pada suatu kelompok atau masyarakat untuk bersosial yang dapat berbentuk kerjasama ataupun interaksi antar individu.

Dari beberapa pendapat di atas, dapat disimpulkan bahwa tujuan dari pendidikan jasmani adalah untuk memberikan keleluasan siswa dalam belajar untuk mengembangkan potensi yang ada dalam dirinya sehingga mampu meningkatkan sumber daya manusia.

\section{Nilai-Nilai dalam Pendidikan Jasmani}

Pendidikan jasmani merupakan suatu bidang kajian yang luas, didalamnya mempelajari tiga (3) ranah sekaligus yaitu kognitif, afektif, dan psikomotor yang tujuannya untuk mengembangkan potensi yang ada dalam diri siswa. Adapun nilai-nilai yang terkandung dalam pendidikan jasmani dari kutipan (Chen \& Liu, 2009:192), sebagai berikut:

1. Motivasi untuk berperilaku positif

Nilai ini mengandung arti bahwa pendidikan jasmani menumbuhkan sikap motivasi kepada siswa terutama sebagai dorongan atau penggerak dalam dirinya untuk berperilaku positif di lingkungan masyarakat.

2. Kegigihan

Kegigihan dalam pendidikan jasmani diartikan untuk memegang teguh pendirian dalam dirinya.

Selanjutnya, pendapat dari (Freire et al., 2018:6) menyatakan bahwa nilai-nilai yang ada dalam pendidikan jasmani, sebagai berikut:

1. Bertanggung jawab

Arti nilai ini yaitu untuk kesadaran diri individu dalam semua tingkah laku dan perbuatan yang disengaja atau tidak disengaja untuk dipertanggung jawabkan. 
2. Aktif

Nilai ini mengandung arti bahwa individu diharapkan untuk tidak berdiam dalam segala kegiatan yang dilaksanakan, seperti beraktivitas, berkomunikasi, dan berdiskusi dengan yang lainnya.

3. Mampu memecahkan masalah

Makna yang terkandung adalah kemampuan individu untuk menghadapi situasi keadaan yang berada di depannya.

Lebih lanjut, pernyataan dari (Yuliawan, 2016) bahwa nilai-nilai yang terkandung dalam pendidikan jasmani, meliputi:

1. Sportivitas

Maksud dari nilai ini adalah untuk dapat bersikap adil terhadap siapapun, dan mau menerima hasil apapaun yang telah didapatkan.

2. Kejujuran

Nilai ini mengandung arti untuk berkata apa adanya dan menjadikan orang-orang percaya terhadapnya.

3. Kerjasama

Kemampuan untuk saling berkoordinasi dengan sesama untuk pencapaian tujuan yang sudah ditetapkan.

Dari beberapa pendapat di atas, dapat disimpulkan bahwa nilai-nilai yang terkandung dalam pendidikan jasmani adalah untuk mempersiapkan pribadi individu menjadi lebih baik dan menjadi contoh di kehidupan bermasyarakat.

\section{Peran Guru Untuk Menerapkan Nilai Pendidikan Jasmani}

Dalam menerapkan nilai-nilai pada pendidikan jasmani, guru diharapkan menetapkan seperangkat nilai inti yang dapat ditanamkan melalui pembelajaran yang proaktif, sehingga memberikan kebebasan kepada peserta didik untuk memiliki kesempatan dan merefleksikan diri dalam memahami pembelajaran (Vickerman \& Maher, 2018). Dari hal tersebut, guru memiliki peranan penting untuk menerapkan nilai-nilai yang ada kepada peserta didik untuk menjadi manusia yang paham akan norma, agama, dan adat istiadat di 
lingkungan masyarakat: Ada beberapa peranan penting untuk guru atau praktisi seperti yang disebutkan oleh (Whitehead et al., 2014), diantaranya:

1. Menghargai perilaku yang baik.

Aspek menghargai pada guru lebih tepatnya adalah memberikan suatu penghargaan atau pujian untuk siswa yang memiliki perilaku baik seperti bisa menghormati guru dan teman lainnya, memiliki sikap yang baik seperti sopan santun dan sebagainya. Dari hal kecil tersebut, siswa merasa diperhatikan sehingga ketika guru memberikan pembelajaran, siswa akan senang dan mengamati dengan seksama pada pembelajaran pendidikan jasmani. Dengan itu, nilai-nilai yang diajarkan akan mudah tersampaikan ke peserta didik.

2. Mengabaikan, atau mungkin menghukum perilaku yang tidak diinginkan.

Peran guru dalam menghukum lebih tepatnya adalah memberikan teguran ataupun ketegasan kepada peserta didik yang menyalahi aturan dan menekankan aturan itu untuk dipatuhi bukan dilanggar. Dengan hal tersebut, nilai-nilai pendidikan jasmani terutama menghormati dan mentaati aturan yang ada akan tertanam pada peserta didik, sehingga akan terbawa di lingkungan masyarakat untuk mentaati aturan setempat.

3. Mencontohkan perilaku yang baik.

Guru adalah sosok yang ditiru oleh peserta didik. Sebagai guru harus mencontohkan hal-hal baik yang membuat peserta didik memiliki perhatian lebih kepada guru. Profesionalitas guru merupakan hal yang penting, baik dalam berperilaku ataupun ketika mengajar. Ketika guru sukses dalam hal tersebut, peserta didik akan mengagumi dan mencontoh perilaku seperti yang guru perlihatkan.

Selanjutnya, (Freire et al., 2018) menyebutkan bahwa nilai-nilai dalam pendidikan jasmani dapat tersampaikan dengan beberapa cara, seperti:

1. Penjelasan guru kepada siswa secara benar mengenai kegiatan yang akan datang.

2. Mendemonstrasikan usulan kelas yang direncanakan. Hal ini dimaksudkan supaya siswa mengembangkan kemampuannya dalam menentukan 
keputusan dan untuk merefleksikan sikap dirinya baik kepada guru ataupun teman satu kelas.

3. Membuat seperangkat aturan yang ditentukan secara kolektif.

4. Melibatkan siswa dalam memecahkan suatu permasalahan dalam pembelajaran.

5. Mengadakan pertemuan antara guru dengan siswa untuk mengidentifikasi masalah yang mengganggu mereka baik dari hubungan pertemanan, keluarga, ataupun sekolah yang mengganggu individu dan kualitas kelas, sehingga dpat mengusulkan cara untuk mengatasi permasalahan. 


\section{BAB III. KESIMPULAN DAN SARAN}

\section{A. Kesimpulan}

Pendidikan jasmani merupakan salah satu pembelajaran yang terstruktur dan sistematis unk memperoleh pengetahuan, peningkatan sikap kepribadian, dan keterampilan melalui aktivitas jasmani. Terdapat nilai-nilai penting yang terkandung dalam pendidikan jasmani seperti, sportivitas, tanggung jawab, kerjasama, kejujuran, dan lain sebagainya. Dibutuhkan suatu peranan dari seorang guru untuk menerapkan nilai-nilai pendidikan jasmani kepada peserta didik untuk menjadi bekal dalam bersikap, berkepribadian, dan berguna di lingkungan masyarakat seperti memberikan contoh yang baik, membuat aturan pada proses pembelajaran, menghargai perilaku siswa yang baik, dan sebagainya.

\section{B. Saran}

Penting bagi guru pendidikan jasmani untuk andil berperan dalam pembentukan peserta didik menjadi manusia yang seutuhnya melalui sikap/contoh perilaku yang baik dihadapan peserta didik. 


\section{DAFTAR PUSTAKA}

Chandler, T., Cronin, M., \& Vramplew, W. (2002). School Sport and Physical Education. In Sport and Policy: Issues and Analysis. Routledge. http://dx.doi.org/10.1016/B978-0-7506-8594-8.00007-3

Chen, A., \& Liu, X. (2009). Task values, cost, and choice decisions in college physical education. Journal of Teaching in Physical Education, 28(2), 192213. https://doi.org/10.1123/jtpe.28.2.192

Dwyer, D. A. N. B. D., \& Gabret, T. J. (2012). Global Positioning System Data Analysis: Velocity Ranges And A New Definition Of Sprinting For Field Sport Athletes. Journal of Strength and Conditioning Research, 26(3), 818824.

Festiawan, R. (2015). Pedagogi Olahraga (Sport Pedagogy). In Universitas Jenderal Soedirman (pp. 1-23).

Freire, E. dos S., Marques, B. G., \& Miranda, M. L. de J. (2018). Teaching values in physical education classes: the perception of Brazilian teachers. Sport, Education and Society, 23(5), 449-461. https://doi.org/10.1080/13573322.2016.1213715

Komarudin. (2017). Psikologi Olahraga (Latihan Keterampilan Mental dalam Olahraga Kompetitif). PT Remaja Rosdakarya.

Laker, A. (2003). The future of physical education: Building a new pedagogy. In The Future of Physical Education: Building A New Pedagogy. Routledge. https://doi.org/10.4324/9780203464892

Suherman, A. (2009). Revitalisasi Pengajaran Dalam Pendidikan Jasmani. UPI.

Vickerman, P., \& Maher, A. (2018). Teaching Physical Education to Children with Special Educational Needs and Disabilities. In Teaching Physical Education to Children with Special Educational Needs and Disabilities. Routledge. https://doi.org/10.4324/9781351206150

Whitehead, J., Telfer, H., \& Lambert, J. (2014). Values in youth sport and physical education. In Sports Coaching Review (Vol. 3, Issue 2). https://doi.org/10.1080/21640629.2015.1035162

Yuliawan, D. (2016). Pembentukan Karakter Anak Dengan Jiwa Sportif Melalui Pendidikan Jasmani Olahraga dan Kesehatan. Jurnal Sportif, 2(1), 101-112. https://doi.org/10.29407/js_unpgri.v2i1.661 